\title{
HIV/AIDS pandemic and agricultural production in Cameroon
}

\author{
M.D. Tambi \\ University of Dschang \\ 96 Boîte Postale, Dschang, Cameroon
}

\begin{abstract}
Whether HIV/AIDS affects agricultural production in Cameroon is purely an empirical issue due to controversy in results over the years. This study has as objectives to assess factors that affect the prevalence of HIV/AIDS and to explore the influence of HIV/AIDS on agricultural production in Cameroon. The 2007 Household Consumption Survey is use as our source of data together with other variables imported into the survey data from the ministries in charge of public health and agriculture. Estimates are obtained using instrumental variables two-stage least squares regression method. The result shows that the prevalence of HIV/AIDS pandemic in Cameroon is strongly influence by level of education, age, occupation and environmental characteristics, while the main result reveals that the prevalence of HIV/AIDS correlates negatively with agricultural production. These results have implications for agricultural policy instruments that could offer interventions to HIV/AIDS affected persons to mitigate the negative effect on agricultural production.
\end{abstract}

Keywords: HIV/AIDS; agricultural production; instrumental variable; Cameroon

\section{Context of study}

Until date agriculture is still the mainstay of Cameroon economy, any pest to hamper agricultural production will have great repercaution in the functioning of the Cameroonian economy. Whereas, United Nations in 2010 noted five principal ways through which HIV/AIDS may affect agriculture: (1) absenteeism caused by HIV related illnesses and deaths leading to declining yields; (2) loss of labour may lead to declines in crop variety and to changes in cropping systems; (3) reduction in labour supply through the loss of workers to HIV/AIDS at crucial periods of planting and harvesting could significantly reduce the size of the harvest, affecting food production; (4) loss of knowledge about traditional farming methods and loss of assets will occur as members of rural households are struck by the disease and so not able to pass on their know-how to sub-sequent generations and (5) loss or reduction of remittances is likely to occur in areas where agricultural workers send money home while working abroad, so when the workers become sick, they can no longer earn money to send home (United Nations, 2010). Associated to these channels, Booysen et al. (2003) introduced six macro channels through which HIV/AIDS is affecting agricultural production: (a) labour supply and demand, (b) capital investmentand utilisation, (c) savings, (d) investment, (e) aggregate demand, (f) GDP and the distribution of income. In confirmation, a study conducted in Thailand by UNAIDS in the year 2000 observed that one third of the rural families affected by AIDS experienced a halving of their agricultural output (UNAIDS, 2000). 
Dwelling on the HIV/AIDS pandemic, HIV/AIDS is known in Cameroon as a second killer disease after malaria; it kills indiscrimately both children and adults after weakening the immune system of the patient. Unlike malaria that can eliminate an individual within a short period of sickness, HIV/AIDS destroys the immune system of an individual gradually; infact Stover and Bollinger (1999) noted that it is different from most other diseases because it strikes people in the most productive age groups and is essentially 100 percent fatal, they equally revealed that the effects will vary according to the severity of the HIV/AIDS epidemic and the structure of the national economies (Stover, Bollinger, 1999). The medical cost associated with this process is too high, making HIV/AIDS a number one terrible disease to humanity; it does not only destroy one internally but it physically weakens an individual as well as stops the individual from participating in the labour market. In all these, the agricultural sector that is practically manually oriented labour is badly tempered and so greatly affecting the agricultural sector.

The Cameroon national AIDS control committee in 2010 explained that HIV and AIDS are different, while the human immunodeficiency virus (HIV) causes the acquired immune deficiency syndrome (AIDS); the AIDS is only a condition that compromises the immune system and leads to opportunistic infections and malignancies, or cancer, and eventually death. HIV/AIDS is an emotion-driven-disease; its principal mode of transmission is through unprotected sex to about 80 percent associated to other transmission means such as: common use of sharp objects (blades, niddles, knifes...) and through pregnancy from mother to child. Emotional issues needs a lot of self discipline to control, thus for the fact that HIV/AIDS is associated to sex is a major trait to the present and future youthful African generation. Most youths are too sex conscious even with the introduction of preservatives (condom) their interest is to get the fullness of sex, others it's the lack of knowledge or the absent of preservatives (this is common with rural Cameroon), all these pushes the youths and even the adults to practice unsafe sex. For these reasons many have died, others are patients and so tempering with the labour market and the production sector in particular with agriculture inclusive.

In Cameroon above 60 percent of its population live in the rural community with about 80 percent involve in agricultural productivity. The government of Cameroon also depends on agriculture for exportation (cocoa, coffee...); it's in these rural communities that the number of infected HIV/AIDS persons is on a rise. Some villages are to remote that they go for months without preservatives even for sale, many are still ignorant of the basic transmission means of the disease, others even belief that HIV/AIDS is in the condom itself, some categorically refused to use condoms with the pretext that 'one cannot attain orgasm using preservatives'. All these have weaken the agricultural production sector and other sectors related to this such as crafts, fishing and the domestication of animals.

Another pest in the rural zones of Cameroon vis-a-vis HIV/AIDS and agriculture is the attitude of those already infected with the virus. There is still a mentality of "I will not die alone". This is a common slogan among infected youths; many either if they are infected in the city will migrate to the villages or move to other urban towns with a mind set of transmitting the virus to other young people. Most made up their minds to become cheerful givers of HIV/AIDS and they are ready to go to any length to do so; however, the tendency is for infected youths in the cities to migrate to the villages and suburbs, 
where they will easily practice unsafe sex with the myopic, short sighted and stereotype rural population. Further, most sex workers based in urban centres (Yaoundé and Douala) when they realised that the issue of HIV/AIDS was become too serious in urban zones especially when they were tested HIV positive, quickly retired to their villages while others continued to move from one town to the other with the aim of looking for money and transmitting the virus, so as not to die alone by practicing unsafe sex. This explains why the rate of infection in villages is on a persistent increase with more youths being the target population. The government of Cameroon has done much through the ministry of public health by set up local HIV/AIDS committee in villages, couple with the activities of the local councils and civil society organisations, yet the rate of HIV infection is still on a rise meaning that much still need to be done to curb this increase. This is why UNAIDS (2009) reveals that Cameroon's HIV prevalence rate is estimated at 5.1 percent, its' the highest rate for the West and Central Africa subregion. All these have great repercussions on agricultural productivity in Cameroon.

UNAIDS in the year 2000 noted that in one way or the other, the impact of HIV/ AIDS is strongly felt on households and agricultural production, since illness and death will lead to increased expenditure, reduced savings and shifts in productivity patterns (UNAIDS, 2000). A joint model developed by UNAIDS and UNICEF in 2000 reveals how increased AIDS death leads to discontinuity in teaching, with many pupils losing/ changing their teachers; this clearly shows how the HIV/AIDS epidemic is impacting on demand for education and health as well as how supply in the health sector might be affected by increasing infection rates in health care workers (UNAIDS, 2000). As observed by UNAIDS in the Yaoundé study of 2009, women were more infected with HIV than men; HIV prevalence rate was 7.8 percent among women and 4.1 percent among men. These prevalence rates were much higher among young women than among men of the same age and HIV prevalence among sex workers tested increased from 5.6 percent in 1990 to 45.3 percent in 2000 and declined to 34 percent in 2007/2008.

Food and Agricultural Organisation revealed in the literature in 2002 that the major impact of HIV/AIDS on agriculture includes serious depletion of human resources, diversions of capital from agriculture, loss of farm and non-farm income and other psychosocial impacts that affect productivity. Couple with the already existing agricultural challenges such as unfavourable international terms of trade, mounting population pressure on land and environmental degradation, the additional impact of HIV/AIDS has to an extend weaken many households in developing countries that are depending on agricultural production for their livelihood (FAO, 2002). Households suffering from the symptoms of opportunistic infections common in people with AIDS such as coughing and shortness of breath, seizures and lack of coordination, difficult or painful swallowing, mental symptoms such as confusion and forgetfulness, severe and persistent diarrhoea, fever, vision loss, nausea, abdominal cramps, and vomiting, weight loss and extreme fatigue, severe headaches, tuberculosis and coma find it difficult to effectively participate in agricultural production in Cameroon (Isaksen el al., 2002).

There are studies in this domain of literature that have shown a clear influence of HIV/ AIDS on agriculture (United Nations, 2010; FAO, 2002) and there are studies that noted that one cannot tell with certainty the ways through which HIV/AIDS will influence HIV/AIDS (Topouzis, 2000), this category of researches held strong that the impact of 
HIV/AIDS on agriculture, both commercial and subsistence, are often difficult to distinguish from factors such as drought, civil war, and other shocks and crises, indicating that unlike famine situations, buying and selling of assets in the case of AIDS is very subtle, done within villages or even among relatives, and the volume is small (FAO, 2002; Topouzis, 2000). As cited in the text of Food and Agricultural Organisation, some literature have explained that, if at all the exits a relationship between HIV/AIDS and agriculture, it will be largely invisible as what distinguishes the impact from that on other sectors is that it can be subtle enough so as to be undetectable. In the words of Regalema, Topouzis noted that even if households are selling cows to pay hospital bills, it is hard to see tens of thousands of cows being auctioned at the market, hence FAO in 2002 confirmed that these reasons, the developmental effect of HIV/AIDS on agriculture continues to be absent from the policy and programme agendas of many African countries (Topouzis, 2000).

Since 2000s until date, many studies on HIV/AIDS that have focused on specific sectors of the economy such as agriculture have been limited to showing the wide variety of impacts and their intensity on issues such as crop yields or on population (FAO, 2002). In this light, we can with certainty underscore that no quantitative empirical data on the economic impact of HIV/AIDS in Cameroon is existing. As Scicchitano and Whitlock earlier noted in 2000; only international studies using models to explore the effect of AIDS on the education and health systems provided information on the potential impact in the country (Scicchitano, Whitlock, 2002).

Most of the studies in this domain are in the macroeconomic literature (Booysen et al., 2003). They noted that the accuracy of the results of macro studies can be faulted for various shortcomings: (1) the current demographic projections and the empirical evidence on the microeconomic impact of the epidemic, (2) the under and overestimation of the likely macroeconomic impacts of the epidemic, tiredness due to more work of quantifying the nature of the impact of the epidemic on specific sectors in the economy, and (3) models are also constrained by a lack of clarity regarding the key question of how treatment, care and support for HIV/AIDS-affected individuals and households are to be financed in governments, given that government at times are unclear as to what policies will be implemented to fights HIV/AIDS. This explains why the approaches, assumptions and results may vary greatly in the macroeconomic models employed in estimating the impact of HIV/AIDS on the South African economy, the overriding message that these models convey remains the same (Booysen et al., 2003).

The few macroeconomic studies that have attempted to quantify the effects of HIV/ AIDS on agriculture have all practically used the same model but different data set. A typical example of the methodology used is already clearly detailed in the literature as demonstrated in Scicchitano and Whitlock (2002) and Booysen et al. (2003). Most of the studies in this domain that used microeconomics analysis focus more on primary data being in Cameroon and outside Cameroon. Most of these studies make use of descriptive and inferential statistics to observe the behaviour of HIV/AIDS vis-a-vis agriculture (Kormawa, 2013; Dawn et al., 2009). Our study is absolutely different from previous studies, its' equally unique in terms of the methodology we intend to used. We shall use the secondary data from the ministry of agriculture and rural development as well as data from the demographic and health survey. We purpose to use the multinomial logit to 
estimate our results. This method has not been used before by another study to quantify the effects of HIV/AIDS on agriculture being in Africa or outside Africa. Thus, to do this, our main objectives are: explore the influence of HIV/AIDS on agricultural production in Cameroon, analyse the factors fuelling the spread of HIV/AIDS in Cameroon, verify the HIV/AIDS effect on agricultural production by gender of household head and proposed some possible economic policies to ameliorate the HIV/AIDS - agricultural production effect.

\section{Literature review}

HIV/AIDS is a very terrible disease and its effects on human health can be very terrifying, it can ridicule a family and bring them to zero vis-a-vis economic wellbeing. Kormawa (2013) over the years has revealed that agricultural labour had declined partly due to the HIV/AIDS pandemic; however, according to her, most governments have reacted to the pandemic by improving access to anti-retroviral drugs. In any case, medically the success of these initiatives rests on the availability of food and the nutritional status of their beneficiaries. Booysen et al. (2003) also noticed that the cost of HIV/AIDS to South Africa will be significant in economic, social and human terms. Hence according to them, given that HIV/AIDS primarily effects the economically and sexually active population, the epidemic poses a serious threat to economic growth, employment, development prospects and poverty alleviation (Booysen et al., 2003). The study of Dawn et al. (2009) in Uganda also confirmed that the HIV/AIDS pandemic threatens economic, social, and environmental sustainability throughout Sub-Saharan Africa.

Isaksen el al. (2002) stresses that women and children are suffering most from AIDS in Africa, and so making agricultural production and food supply to drop, families and communities to break apart and young people's future to becomes insecure. Isaksen el al. (2002) also examined the available evidence for the more important private and public sectors. Here we observed that the biggest challenge in agriculture appears to be the overall decline in food production where even if one takes AIDS out of the equation Africa will have difficulty in maintaining basic food production over the next two decades (Isaksen el al., 2002). The study of Hamusimbi et al. (2006) indicated that HIV and AIDS related morbidity and mortality affect agriculture and food security due to their negative effects on labour productivity and the erosion by such impacts of productive assets base of affected households.

Considering the case of Kenya, Ndirangu and Kimalu (2012) unanimously accepted that HIV/AIDS has shown a downward trend in the recent years and has impacted negatively on agricultural production and food security in rural areas. Using a sample of 212 households, their study examines changes in welfare of households experiencing death and illness associated with HIV/AIDS condition. In terms of result they observed that poverty incidence and severity are observed to be higher among affected and nonaffected households which partly are explained by lower crop and livestock production. It therefore appears that poverty seems to reinforce the spread of the HIV/AIDS and that once AIDS strikes becomes a driver of poverty intervention strategies need to deal with poverty and HIV/AIDS problems concurrently (Ndirangu, Kimalu, 2012). In examining the effects of HIV/AIDS on economic aggregates, Hamusimbi et al. (2006) 
revealed that the HIV/AIDS pandemic resulted in reduction in labour hours on agricultural activities, reduced number of working adults in households, the female abandonment of agricultural activities, the detriment of households, increased the number of female headed households and orphans. All these have increased health and funeral costs, erodes the income and household endowments and hence leaving much land bare for agriculture while households affected by HIV and AIDS related illnesses and deaths resort to the sale of productive assets to meet their immediate and pressing income demands (Hamusimbi et al., 2006).

In a qualitative study exploring interrelationships between HIV/AIDS, labour availability, agricultural productivity, household resources, food consumption and health status in rural south-eastern Uganda, Dawn et al. (2009) reported an increase in widow and orphan headed households; labour shortages due to illness and caretaking; degradation of household resources from health related expenses; loss of land tenure and assets following deaths, especially for widows and orphans; and changes in agricultural practices and productivity. Their study highlighted a potential downward spiral of livelihood degradation for vulnerable households and suggested targeted interventions to improve sustainability. In the same light, in Tanzania and other countries, Stover and Bollinger (1999) have shown that AIDS will have adverse effects on agriculture, including loss of labour supply and remittance income (Ilinigumugabo, 1996). In further explanation, they intimated that the loss of a few workers at the crucial periods of planting and harvesting can significantly reduce the size of the harvest, while a loss of agricultural labour is likely to cause farmers to switch to less labour intensive crops (Stover, Bollinger, 1999).

Agbor and Tambi (2014) attempted to carry out a comprehensive analysis of the determinants of HIV/AIDS epidemics prevalence in Cameroon. They show that factors such as: marital status, education in complete years of schooling, labour participation, sex of household head, occupation, household residence, frequency of listening to the radio and wealth status are strong determinants of HIV/AIDS prevalence in Cameroon. In their study, the result by age group reveals that age group 15 to 24 years is hardest hit by HIV/AIDS and second by 25 to 34 years while result by education level shows that HIV/AIDS affected more, people who did not go to school due to their inadequate knowledge in HIV/AIDS issues. These results simply indicated that people in agricultural production were affected more since they are the least educated in Cameroon.

\section{Theoretical consideration and methodology of study}

\section{Theoretical consideration}

As regards this framework, Dow (1999) explains that labour productivity depends on factors like physical and mental capabilities, investments in human capital, efficiency of labour organization and management and emphasizes that changes in health could affect labour productivity, especially household agricultural productivity. On the other hand, agricultural labour productivity could be reduced by the need to care for the sick relatives or by reducing years of schooling if parents are chronically ill while improvements in health could positively affect the experience level of the work force by increasing their life expectancy and good health status condition. The magnitude of these issues suggests that understanding the way in which mothers with dependent children make work decisions 
is a crucial area of study. An accurate conceptualization of the perceived opportunities and costs associated with different labour participation decisions for a range of individuals from different geographic areas, cultural groups and educational and socioeconomic levels, will assist organizational and public policy makers to maximize the potentially positive impact and reduce the potentially negative impact, of these issues on individuals, families and society.

Theoretically, we make use of microeconomics labour supply theory which proposes that an individual chooses to participate in the labour force if the value of her market wage is greater than her reservation wage, defined as the value of her time at home (Joesch, 1997) and if the health of the individual permit so. This decision results in an "opportunity cost of time" which is defined as the value of what an individual forgoes in order to spend his/her time in the way he/she does (Hofferth, 1996). For example, if a man works for pay, he can no longer spend that time working at home and vice versa and if an individual is sick, then he cannot work at all. In our study, we are concern with the time an individual sacrifices to work in the farm in other to contribute to reduce the problem of agricultural production (Leibowitz, Klerman, 1995).

To deal with the time factor, we used the economic model of the family developed by Becker (1965) to analyze the consequences of maternal labour supply. In this case, the family's objective is assumed to be the maximization of the utility that it derives from consuming the various goods that it produces using inputs of family members' time and market-purchased goods and services, while food security services are viewed as consumption good from which parents derive utility. The family's level of consumption of these services depends on the quantity of food that it produces (Blau, Grossberg, 1990).

\section{Methodology of study}

The current outbreak of HIV/AIDS can be an appropriate framework for measuring agricultural production in Cameroon as condition by the ratio of people involve in agricultural production that are infected by HIV/AIDS virus, thus modeling econometrically the effects of HIV/AIDS on agricultural production in Cameroon; we apply the following equation of interest:

$$
A P_{i}=\Phi+\bar{\lambda} H I V_{a g}+\psi \pi_{i}+\varepsilon_{i},
$$

where $A P_{i}$ is agricultural production which is our outcome variable of interest; $H I V_{a g}$ is simply individuals infected by HIV/AIDS in the agricultural production households; $\pi_{i}$ represent a vector of exogenous demographics of maternal, paternal, child and environmental characteristics while $i$ is the unit of observation of agricultural production in Cameroon. In econometrics, $\bar{\lambda}$ portrays the actual effect of HIV/AIDS on agricultural production. In addition, $\Phi, \psi$ are parameters to be estimated, while $\varepsilon$ is the error term respectively.

Given that there can be some biases due to omitted variables, it will be possible that the covariance of $H I V_{a g}$ and the error term $(\varepsilon)$ is not equal to zero, hence making our result inconsistent. To redress this situation, we identify an instrument variable $M$, the instrument is a factor that affects HIV/AIDS without directly influencing agricultural 
production, in other words it's a variable that can partially determines HIV/AIDS in agricultural production households but is uncorrelated with the error term. The agricultural production generating function may take the following structural form:

$$
H I V_{a g}=\Phi_{A P}+\bar{\lambda}_{A P} M_{i}+\gamma_{A P} \pi_{i}+\mu_{i} .
$$

The instrument use in our study is access to the medical centre, with such an instrument we can estimate a two stage regression model with the first stage equation as indicated in equation (2) above. As Morrill (2008) indicated in the literature, the consistency of the estimate of $\bar{\lambda}$ relies on the validity of the access to the medical centre as our instrument. Thus, as $M$ is uncorrelated with $\varepsilon$, then the instrumental variable estimate of $\bar{\lambda}$ is consistent. Morrill noted that this is fundamentally an untestable assumption. Everything being equal, our model can be estimated by taking the predicted value of HIV/AIDS from equation (2) and substituting it in for HIV/AIDS in equation (1) in an IV 2SLS model. Based on the introduction of instrumental variables, Tambi (2014) explained that Mwabu (2009) mentioned three properties of an instrument that need to be noted at the outset. First, an instrument is relevant if its effect on a potentially endogenous explanatory variable is statistically significant. Second, an instrument is strong, if the size of its effect is 'large'. Finally, the instrument is exogenous if it is uncorrelated with the structural error term. An instrumental variable that meets all these requirements is a valid instrument.

Endogeneity can arise due to: errors-in-variables, omitted variables and simultaneous causality (Bascle, 2008). Endogeneity and heterogeneity bias can compromise the validity of OLS estimators. The IV approach is intended to oxygenize the endogenous regressors using valid, relevant and strong instrument and the most commonly used IV estimation method is the single equation approach of two-stage least squares (2SLS) estimators (Jones, 2007).

Murray (2006) suggested the strategy for supporting instrument validity, that is we test over-identifying restrictions using Sargan's test statistic $\left(n R^{2}\right)$ which has a chi-square distribution with degrees of freedom equal to $(l-q)$, the degree of over-identification (where $n$ is the sample size, $R^{2}$ is from first-stage regression showing the strength of the instrumental variable, $l$ is the number of IVs and $q$ is the number of endogenous variables). This test the null hypothesis that all instruments are valid, hence failing to reject signifies instrument validity. Murray (2006) shows that the bias of 2SLS approach grows with the number of IVs $(l)$, declines as sample size $(n)$ rises and as the strength of the IVs $\left(R^{2}\right)$ increases. Thus, as long as $n R^{2}$ is larger than $l$, (which will often hold true if the instruments are strong), 2SLS has smaller bias than OLS.

Considering the reduce form estimate, we remark that the 2SLS estimate of $M$ can also be thought of as resulting from the division of the reduced form estimate $\bar{\lambda}_{A P}$ below, by the first-stage coefficient derived above $M$ (Morrill, 2008). The reduced form equation is the regression of the agricultural production outcome on the instrument. This actually indicates whether the instrument is correlated with the outcome variable of interest.

$$
A P_{i}=\Phi_{A P}+\bar{\lambda}_{A P} M_{i}+\gamma_{A P} \pi_{i}+\sigma_{i} .
$$

Evaluating our endogenous variable, Angrist (1999) reveals that 2SLS estimate is a reasonable estimation strategy with limited dependent variables and a continuous 
endogenous variable. Since our variable of interest is a continuous variable with a continuous endogenous variable, this makes our model of instrumental variable robust in terms of estimations.

\section{Data presentation}

Our data is practically from secondary sources, we shall use principally the household consumption survey (HCS); however, we shall import the HIV/AIDS variable from records of the Department of Statistics of Ministry of Public Health, given that this variable is not capture in the household consumption survey. It therefore becomes relevant to import it from tangible and authentic source such as the Ministry of Public Health in Cameroon. We shall equally import crop production (plantain, cassava, etc.) as our main endogenous variable and other variables such as farm size, use of fertilizer and subsidies from support institutions from Ministry of Agriculture and Rural Development. Most of our exogenous variables such as marital status, education in complete years of schooling, labour participation, sex of household head, occupation, household residence, frequency of listening the radio, wealth index and the use of condom in sex are from the household consumption survey and all these data was collected in 2007.

The household consumption survey was collected by the National Institute of Statistics under the the Ministry of Economic Affairs, Programming and Regional Development as the executing agency. This survey was collected in 2011 with about 11391 variables collected from all the 10 regions, plus the two metropolitan cities (Douala, Yaoundé) in Cameroon. The principal respondents were women of 15-59 years of age with 50 percent of men respondent; all men and women of productive age especially in the agricultural sector. The target population is also that which is prone to having HIV/AIDS, making our study fitted to produce adequate and robust results.

\section{Empirical result}

\section{Weighted sample descriptive statistics}

Medically, in course of 2011 about 5.8 percent of Cameroonian households had at least a member with HIV/AIDS positive giving a minimum of 200 and a maximum of 8700 households, this high maximum value signify that the rate of HIV/AIDS prevalence in Cameroon is on a rise. Among these households only 50 percent are consistently going to the medical centres for medical check up and so most individuals have a high probability of having advanced stage of illness. The more an individual do health checks the lower the probability of living with an illness without knowing, that is why it's often said prevention is better than sacrifice. However, the lack of checked up may be due to high consultation cost that is as high as 99.997 thousand depending on the type of illness and the hospital in question (health centres, private, para-public and public hospitals). The low rate of medical consultation can be explain by the fact that 75.6 percent of the farmers are working full time in agriculture which occupy a majority of their time to the extent that it's difficult to visit hospitals.

Considering the situation of agriculture, we observed that a majority of the households involved in agricultural production, produces food crops, in fact this is a common 
phenomenon with women with crops such as: yams, cassava, potatoes, plantains, maize and beans, are commonly produced. Among these farmers, only 7.6 percent used modern agricultural technology, 54 percent of them are landlords while the rest are either doing shared cropping or working on leased farms. The cost of farm inputs is low when they are the ones providing their own seeds, labour and composing the organic manure and becomes very expensive when these services are provided by a second or third party. The annual rainfall is about 216.35 millilitres in March when rain just start falling and rose to about 941.08 annual precipitation which can be around August, this climate characteristic helps to increase production in their averagely large farms.

Table 1

Weighted sample statistics of selected variables

\begin{tabular}{|l|c|c|c|c|c|c|}
\hline \multicolumn{1}{|c|}{ Variables } & Obs & Weight & Mean & Std. dev. & Min & Max \\
\hline Food crop production & 11391 & 4069790.9 & 11.2476 & .5897181 & 10.565 & 12.599 \\
\hline HIV/AIDS positive & 11391 & 4069790.9 & .0581412 & .0228167 & 200 & 8700 \\
\hline Cost of medical consultation & 11391 & 4069790.9 & 402.6639 & 1599.895 & 0 & 99.997 \\
\hline Always go in for medical check-up & 11391 & 4069790.9 & .4897709 & .4999667 & 0 & 1 \\
\hline Use modern agricultural equipment & 11391 & 4069790.9 & .0766127 & .2659877 & 0 & 1 \\
\hline Farmer owns land & 11391 & 4069790.9 & .5393308 & 4984726 & 0 & 1 \\
\hline Married respondent & 11391 & 4069790.9 & .5777995 & .4939318 & 0 & 1 \\
\hline Climate change & 11391 & 4069790.9 & 470.2544 & 235.7421 & 216.35 & 941.08 \\
\hline Primary education & 11391 & 4069790.9 & .3360917 & .4723914 & 0 & 1 \\
\hline Secondary education & 11391 & 4069790.9 & .3210247 & .4668907 & 0 & 1 \\
\hline Farmer works full time in agriculture & 11391 & 4069790.9 & .7562125 & .7329732 & 0 & 7 \\
\hline Log of cost of seeds & 11391 & 4069790.9 & 1.806159 & 1.165779 & 0 & 8.294 \\
\hline Log of farm size in hectares & 11391 & 4069790.9 & 9.68209 & .602148 & 8.825 & 10.59 \\
\hline Less than 30 years & 11391 & 4069790.9 & .2356156 & .4244016 & 0 & 1 \\
\hline Between 30 and 39 years & 11391 & 4069790.9 & .2568366 & .4369077 & 0 & 1 \\
\hline Between 40 and 49 years & 11391 & 4069790.9 & .2038819 & .4028999 & 0 & 1 \\
\hline Urban residence & 11391 & 4069790.9 & .3701806 & .4828741 & 0 & 1 \\
\hline
\end{tabular}

Source: Computed by the author from 2007 Cameroon household consumption survey and MPH.

Focusing on the social aspect of households, we observed that 57.7 of households are married with 37 percent of them living in urban centres. A majority of the household heads especially in agricultural production had but primary and secondary education. The households are predominated by the age group 30 to 39 years, implying that Cameroon still have a growing population. All of this information is summarised in table 1.

\section{Determinants of HIV/AIDS pandemic in Cameroon}

The prevalence of the HIV/AIDS pandemic in Cameroon is strongly influence by level of education, age,occupation and environmental characteristics. This result is consistent with the observation of Agbor and Tambi (2014) using an alternative data source. 
Тамби М.Д. Вестник РУДН. Серия: Экономика. 2019. Т. 27. № 1. С. 72-89

Table 2

Determinant of average annual rainfall variation and production effects

\begin{tabular}{|c|c|c|c|}
\hline Variables & Reduced form & OLS & 2SLS \\
\hline \multirow[t]{2}{*}{ HIV/AIDS positive } & $\mathrm{n} / \mathrm{a}$ & $-0.326438^{\star \star \star}$ & $-0.38981^{\star \star}$ \\
\hline & $\mathrm{n} / \mathrm{a}$ & -20.42 & -2.43 \\
\hline \multirow[t]{2}{*}{ Cost of medical consultation } & $7.43 e-07^{\star}$ & $\mathrm{n} / \mathrm{a}$ & $\mathrm{n} / \mathrm{a}$ \\
\hline & 1.76 & $\mathrm{n} / \mathrm{a}$ & $\mathrm{n} / \mathrm{a}$ \\
\hline \multirow[t]{2}{*}{ Always go in for medical check-up } & -0.0031336 ** & $\mathrm{n} / \mathrm{a}$ & $\mathrm{n} / \mathrm{a}$ \\
\hline & 2.16 & $\mathrm{n} / \mathrm{a}$ & $\mathrm{n} / \mathrm{a}$ \\
\hline \multirow[t]{2}{*}{ Use modern agricultural equipment } & 0.0029879 & -.0149393 & $0.1619038^{\star \star \star}$ \\
\hline & 1.25 & -0.64 & 4.06 \\
\hline \multirow[t]{2}{*}{ Farmer owns land } & 0.0004223 & $0.1014575^{\star \star \star}$ & $0.1248819^{\star *}$ \\
\hline & 0.22 & 5.00 & 2.13 \\
\hline \multirow[t]{2}{*}{ Married respondent } & -0.0000546 & 0.0224042 & -0.0090842 \\
\hline & -0.04 & 1.32 & -0.11 \\
\hline \multirow[t]{2}{*}{ Climate change } & $1.86 \mathrm{e}-06^{\star *}$ & $-0.0004155^{\star \star \star}$ & $2.67 e-07$ \\
\hline & 2.56 & -12.46 & 0.00 \\
\hline \multirow[t]{2}{*}{ Primary education } & $0.0012011^{\star \star \star}$ & $0.0569568^{* * *}$ & $0.1727172^{\star}$ \\
\hline & 2.68 & 3.04 & -1.66 \\
\hline \multirow[t]{2}{*}{ Secondary education } & $0.0010154^{\star \star}$ & $-0.1451996^{\star \star \star}$ & $-0.2509877^{\star \star}$ \\
\hline & 2.47 & -6.51 & -2.01 \\
\hline \multirow[t]{2}{*}{ Farmer works full time in agriculture } & $0.0022824^{\star \star}$ & .0022034 & $0.1384358^{\star}$ \\
\hline & 2.01 & 0.17 & 1.68 \\
\hline \multirow[t]{2}{*}{ Log of cost of seeds } & 0.0007562 & $0.0160131^{\star \star}$ & $0.0735438^{\star \star}$ \\
\hline & 1.19 & 2.36 & 1.79 \\
\hline \multirow[t]{2}{*}{ Log of farm size } & $0.0027815^{\star \star}$ & $0.3473115^{\star * *}$ & $0.4127794^{\star \star \star}$ \\
\hline & 2.09 & 24.68 & 3.99 \\
\hline \multirow[t]{2}{*}{ Less than 30 years } & $0.0006865^{\star \star \star}$ & $0.1666005^{\star \star \star}$ & $0.248927^{\star}$ \\
\hline & 3.30 & 7.08 & 1.90 \\
\hline \multirow[t]{2}{*}{ Between 30 and 39 years } & $0.0016522^{*}$ & $0.1187382^{\star \star \star}$ & 0.1882064 \\
\hline & 1.84 & 5.75 & 1.59 \\
\hline \multirow[t]{2}{*}{ Betwee 40 and 49 years } & $-0.0041698^{\star *}$ & $0.0996151^{* * *}$ & -.0884291 \\
\hline & -2.06 & 4.83 & -0.55 \\
\hline \multirow[t]{2}{*}{ Urban place of residence } & -0.0030819 & $0.2355333^{* * *}$ & .0646896 \\
\hline & -1.55 & 11.04 & 0.47 \\
\hline \multirow[t]{2}{*}{ Constant } & $0.0237562^{\star *}$ & $8.223914^{\star \star *}$ & $10.35387^{\star \star \star *}$ \\
\hline & 1.91 & 62.37 & 10.74 \\
\hline$R^{2} /$ Pseudo- $R^{2}$ & 0.1265 & 0.7300 & 0.9866 \\
\hline \multirow[t]{2}{*}{ F-Stat. [df; $p$-value] } & 72.74 & 95.78 & 42.19 \\
\hline & {$[13,11377 ; 0.0000]$} & {$[14,3119 ; 0.0000]$} & {$[14,1048 ; 0.0006]$} \\
\hline
\end{tabular}




\begin{tabular}{|l|c|c|c|}
\hline \multicolumn{1}{|c|}{ Variables } & Reduced form & OLS & 2SLS \\
\hline $\begin{array}{l}\text { F-test of excluded instruments / Joint F / } \chi^{2} \\
\text { ( } p \text {-value) test for Ho }\end{array}$ & $\mathrm{n} / \mathrm{a}$ & $\mathrm{n} / \mathrm{a}$ & 12.43 \\
\cline { 2 - 4 } & $\mathrm{n} / \mathrm{a}$ & $\mathrm{n} / \mathrm{a}$ & {$[12,1047 ; 0.0009]$} \\
\hline \multirow{2}{*}{ Angrist - Pischke multivariate F-test } & $\mathrm{n} / \mathrm{a}$ & $\mathrm{n} / \mathrm{a}$ & 4.903 \\
\cline { 2 - 4 } & $\mathrm{n} / \mathrm{a}$ & $\mathrm{n} / \mathrm{a}$ & {$[0.0062]$} \\
\hline $\begin{array}{l}\text { Cragg - Donald F-Stat. [10\% maximal IV } \\
\text { relative bias] }\end{array}$ & $\mathrm{n} / \mathrm{a}$ & $\mathrm{n} / \mathrm{a}$ & {$[12.426$} \\
\cline { 2 - 4 } Sargan statistic: (Chi-sq(2) $p$-value) & $\mathrm{n} / \mathrm{a}$ & $\mathrm{n} / \mathrm{a}$ & 0.962 \\
\cline { 2 - 4 } & $\mathrm{n} / \mathrm{a}$ & $\mathrm{n} / \mathrm{a}$ & {$[0.8038]$} \\
\hline \multirow{2}{*}{ Durbin - Wu - Hausman $\chi^{2}$ test } & $\mathrm{n} / \mathrm{a}$ & $\mathrm{n} / \mathrm{a}$ & 41.956 \\
\cline { 2 - 4 } & $\mathrm{n} / \mathrm{a}$ & $\mathrm{n} / \mathrm{a}$ & {$[0.0000]$} \\
\hline Observations & $\mathbf{1 1 . 3 9 1}$ & $\mathbf{1 1 . 3 9 1}$ & $\mathbf{1 1 . 3 9 1}$ \\
\hline
\end{tabular}

Source: Author from 2007 HCS; N/B: values below coefficient represent robust t-statistics.

As concerning the level of education, table 2 column one, shows that households with primary education are more susceptible to having HIV/AIDS as compared to households with secondary education. Education and awareness is tantamount to good health, thus, the more enlighten a household become, the higher the tendency for that household to be in good. An educated household will always adopt itself in a way to maximize every medical opportunity so as to play safe as well as live in an objective manner to avoid behaviors that will temper with their health situation.

Age is another element strongly correlating with HIV/AIDS pandemic, thus, the result shows that less than 39 years which is a population group predominated by youths. This age group is characterized by: excitement, discoveries, myopic and stereotypic nature that urges them to engage in all sorts of fantasies and unprotected sexual exercises and by so doing promoting HIV. On the other hand households of age greater than 39 years is the married population, thus with their single partner relationship HIV/AIDS pandemic is reduced. This result is consistent with the observation of UNAIDS in 2009, that women were more infected with HIV than men and that HIV prevalence rate was 7.8 percent among women and 4.1 percent among men. These prevalence rates were much higher among young women than among men of the same age and HIV prevalence among sex workers tested increased from 5.6 percent in 1990 to 45.3 percent in 2000 and declined to 34 percent in 2008 .

In terms of occupation, we observed that full time farming occupation, especially in the case of large farm size farmers in rural Cameroon are more susceptible to acquiring HIV/AIDS. In most rural Cameroon, condoms and knowledge about safe sex preventive measures are absents and hence the probability to contract the virus is very high, more so the nature of their job makes them vulnerable to HIV/AIDS in the sense that they go to the farm early, work tirelessly with the only distraction being sex, especially for the singles. 
Environmental characteristics suchas extreme rain fall or cold may rather push individuals to seek for comfort from opposite sex, it's likely that extreme weather conditions are sexually motivating this can only be achieve by singles through sex and the more they do this so they develop addiction that has a probability of increasing human immunodeficiency syndrome. In the same way, medical check-up, married couples, greater than 40 years and urban residence are not correlating with HIV and AIDS in Cameroon.

\section{Agricultural production and HIV/AIDS effects}

Both the two stage least square and the ordinary least square results shows that the HIV/AIDS pandemic is strongly negatively correlating with agricultural production in Cameroon. This means that as the number of HIV/AIDS persons increases, the quantity of agricultural production drops. Principally HIV/AIDS affects the old, young, adolescents as well as economically productive age group. The symptoms of the virus are: unexplained weight loss, incessant coughing, persistent diarrhoea, persistent fever, coated tongue, rashes and skin infections. Other symptoms in adults include anaemia, tuberculosis, thrush, constipation, heart burn, anorexia (appetite loss), nausea and vomiting. As revealed in the literature; the virus enters human cells and multiplies thereby destroying host cells and as well depletes immune cells. This virus is transmitted through body fluids such as blood and sexual fluids (sperms and semen). As well as undergo six stages developments: HIV infection, window period, seroconversion, asymptomatic HIV infection, related illnesses and AIDS. This process of development totally hinders typical agricultural farmers from giving the maximum time possible for production as they are supposed to. The illness is also associated with much expenditure which reduces the quantity of farm inputs, all these makes farmers to produce below capacity and hence negatively affecting agricultural production. This also means that the consumption-labour-balance principle; that implies the peasant household will increase its work until it meets (balances) the needs (consumption) of the household will not work-out in the case of HIV/AIDS patients, talk-less of meeting up with the food security problem.

The result of the 2SLS is stronger in magnitude as compare to the result of the OLS, in addition, the Durbin - Wu - Hausman test of 41.956 [0.0000] revealed that there is no problem of endogeneity and if at all it existed, it is solved. The Sargan statistics test of 0.962 [0.8038] indicate that the instrument used in the study are relevant and so valid. However, the Cragg Donald test of 12.426 [19.93] shows that though our instruments are valid, they are weak, and it's already revealed in the literature that relevant but weak instruments are still very valid for inference. It just depends on the predictive power of the instruments, in our case, the two instruments use have a strong power of influence making the 2SLS result robust and appropriate for discussion.

Our result shows that the factors contributing to increase agricultural production include the following: use of modern equipment for cultivation, ownership of land, farm size, cost of seeds, number of workers in fulltime agriculture, less than 39 years workers focus on agriculture and having primary education. The use of agricultural modern equipments by farmers in Cameroon is a major contributor to the performance of agricultural workers in terms of increase farm production. Modern equipments reduces labour time of workers, increases the farm land size under consideration and reduces 
farm expenditure, by so doing more seeds are planted on the increase land space, hence augmenting farm produced. The ownership of land reduces the cost of agricultural expenditure, creates concentration given that they are working on their own farms, there is a higher probability of doing the best to achieve a higher agricultural production. Farm size absorb many farm workers, increase quantity of seed to be planted and thus, increasing agricultural production in Cameroon.

Seeds are major agricultural inputs as they directly multiply to yield output, implying that when the cost of these inputs is high, the lower it will be planted and consequently reducing the quantity of farm production. This explains why most farmers will often want to maximized seeds planting on their farmers; most peasants will also want to produce the seeds themselves. Since agriculture is labour intensive, the more the number of workers in full-time activities, the greater the production as to otherwise. Over the years, agriculture is characterise by workers or employers who did not school, thus most people in the agricultural job are primary school leavers. Considering that it is a labour intensive job, workers less than 39 years are more productive ceteris paribus.

\section{HIV/AIDS effect on agricultural production by marital status and place of residence}

\section{Correlates of marital status}

The effect of HIV/AIDS in both the married and single is very strong on agricultural production; however, the effect is heavier for the singles as compared to the married in terms of their magnitude. This result implies that though the married and singles HIV/ AIDS patients are negatively affecting agricultural production, the situation is worse with the single. Most of the married people have settled homes with either family relatives or children. As already mention in population geography, most homes in Cameroon have medium and large family sizes, in fact an average home in Cameroon has between 5-10 persons thus despite the health situation of the family heads, and the challenge to feed their children or family members living with them is high. The probability to work in their farms so as to overcome this challenge is also high. This situation is worse in the case the household heads depends on agriculture for survival and to send their children to school. In such a case they will do everything in their power to produce so as to meetup with these life constraints. In all these, the married have people that carter/comfort for them in times of crisis, this helps to lessen the burden and trauma of the illness on them.

The burden of the illness on singles is stronger because the number of persons under their charge is few so the burden and time sacrifice to produce is also small.

Table 3

HIV effect on agricultural by marital status and place of residence

\begin{tabular}{|l|c|c|c|c|}
\hline \multirow{2}{*}{ Variables } & \multicolumn{2}{c|}{ Marital status } & \multicolumn{2}{c|}{ Geographical place of residence } \\
\cline { 2 - 5 } & Married & Single & Urban & Rural \\
\hline HIV/AIDS positive & $-54.561^{\star *}(2.20)$ & $-25.076(1.58)$ & $28.574(0.37)$ & $-66.682^{\star *}(2.34)$ \\
\hline $\begin{array}{l}\text { Use modern agricultural } \\
\text { equipment }\end{array}$ & $0.158(0.93)$ & $0.073(0.70)$ & $-0.067(0.29)$ & $0.201(0.99)$ \\
\hline Former owns land & $0.040(0.33)$ & $0.193^{\star *}(2.52)$ & $0.199(0.81)$ & $0.267(1.55)$ \\
\hline
\end{tabular}


End to Table 3

\begin{tabular}{|c|c|c|c|c|}
\hline \multirow{2}{*}{ Variables } & \multicolumn{2}{|c|}{ Marital status } & \multicolumn{2}{|c|}{ Geographical place of residence } \\
\hline & Married & Single & Urban & Rural \\
\hline Married respondent & $\mathrm{n} / \mathrm{a}$ & $\mathrm{n} / \mathrm{a}$ & $-0.098(0.47)$ & $-0.053(0.45)$ \\
\hline Climate change & $-0.000^{\star *}(2.12)$ & $0.001^{* \star *}(5.22)$ & $-0.001(0.61)$ & $-0.000(0.39)$ \\
\hline Primary education & $-0.222^{\star}(1.75)$ & $-0.075(1.00)$ & $0.207(0.62)$ & $-0.192(1.43)$ \\
\hline Secondary education & $-0.387^{\star *}(2.24)$ & $-0.083(0.61)$ & $0.106(0.39)$ & $-0.283^{\star}(1.65)$ \\
\hline $\begin{array}{l}\text { Farmer works full time in } \\
\text { agriculture }\end{array}$ & $0.144(1.45)$ & $0.024(0.42)$ & $-0.043(0.28)$ & $0.171(1.47)$ \\
\hline Log of cost of seeds & $0.057(1.45)$ & $0.031(0.86)$ & $0.033(0.71)$ & $0.094(1.57)$ \\
\hline Log of farm size & $0.528^{\star * \star}(4.66)$ & $0.148^{\star \star \star}(2.68)$ & $0.835^{\star \star}(2.07)$ & $0.449^{\star *}(2.40)$ \\
\hline Less than 30 years & $0.546^{\star *}(2.60)$ & $-0.003(0.02)$ & $-0.047(0.16)$ & $0.266(1.55)$ \\
\hline Between 30 and 39 years & $0.212(1.63)$ & $0.140 *(1.68)$ & $0.065(0.36)$ & $0.193(1.26)$ \\
\hline Betwee 40 and 49 years & $-0.016(0.12)$ & $0.072(0.53)$ & $-0.105(0.32)$ & $-0.244(0.95)$ \\
\hline Urban place of residence & $0.144(1.15)$ & $0.205(1.61)$ & $\mathrm{n} / \mathrm{a}$ & $\mathrm{n} / \mathrm{a}$ \\
\hline Constant & $9.105^{\star \star \star}(9.19)$ & $10.581^{\star \star *}(15.72)$ & $2.116(0.30)$ & $10.172^{\star \star *}(10.33)$ \\
\hline$R^{2} /$ Pseudo- $R^{2}$ & 0.9903 & 0.9979 & 0.9955 & 0.9846 \\
\hline F-Stat. [df; $p$-value] & $\begin{array}{c}12.49[13,646 \\
0.0005]\end{array}$ & $\begin{array}{l}28.23[13,389 \\
0.0000]\end{array}$ & $\begin{array}{c}19.93[13,373 \\
0.0000]\end{array}$ & $\begin{array}{c}20.95[13,662 \\
0.4957]\end{array}$ \\
\hline $\begin{array}{l}\text { F-test of excluded instruments/ } \\
\text { Joint } \mathrm{F} / \chi^{2}(p \text {-value }) \text { test for Ho }\end{array}$ & $\begin{array}{l}2.08[2,645 \\
0.1252]\end{array}$ & $\begin{array}{l}0.86[2,388 \\
0.0240]\end{array}$ & $\begin{array}{c}11[2,372 \\
0.0116]\end{array}$ & $\begin{array}{l}2.22[2,661 \\
0.0093]\end{array}$ \\
\hline $\begin{array}{l}\text { Angrist - Pischke multivariate } \\
\text { F-test }\end{array}$ & $4.239[0.1201]$ & $1.778[0.4110]$ & $0.239[0.0875]$ & $4.512[0.1047]$ \\
\hline $\begin{array}{l}\text { Cragg - Donald F-Stat. [10\% } \\
\text { maximal IV relative bias] }\end{array}$ & $2.085[19.93]$ & $0.860[19.93]$ & $10.115[19.93]$ & $2.221[19.93]$ \\
\hline $\begin{array}{l}\text { Sargan statistic: }(\mathrm{Chi}-\mathrm{sq}(2) \\
p \text {-value) }\end{array}$ & $0.343[0.0583]$ & $3.170[0.0050]$ & $0.002[0.0676]$ & $0.073[0.0876]$ \\
\hline $\begin{array}{l}\text { Durbin }- \text { Wu }- \text { Hausman } \chi^{2} \\
\text { test }\end{array}$ & $27.587[0.0000]$ & $1.489[0.0024]$ & $0.647[0.0210]$ & $50.135[0.0000]$ \\
\hline Observations & 6.455 & 4.925 & 6.365 & 5.026 \\
\hline
\end{tabular}

Source: Author from 2007 HCS; N/B: values below coefficient represent robust t-statistics.

\section{Conclusion}

This study has as objectives to: explore the influence of HIV/AIDS on agricultural production in Cameroon, analyse the factors fuelling the spread of HIV/AIDS in Cameroon, verify the HIV/AIDS effect on agricultural production by gender of household head and proposed some possible economic policies to ameliorate the HIV/AIDS agricultural production effect. The household consumption survey is use as our principal source of data with other variables imported from Ministry of Public Health and Agriculture. Estimates will be obtained from STATA 12.0 through the use of instrumental variables.

The main result shows that the HIV/AIDS pandemic is strongly negatively correlating with agricultural production in Cameroon, meaning as the number of HIV/AIDS persons increases, the quantity of agricultural production drops while the prevalence of the HIV/ AIDS pandemic in is influence by the level of education, age, occupation and environmental characteristics. 
In terms of policy, HIV/AIDS has multiple impacts on agriculture and the livelihoods of households which are only slowly being understood. This will gradually help in identifying the kind of agricultural policy instrument that could offer appropriate support to HIV/AIDS affected households. This will ensure that hard-won gains in poverty reduction are not eroded by the pandemic's effect on agricultural growth.

(C) Tambi M.D., 2019

This work is licensed under a Creative Commons Attribution 4.0 International License

\section{Reference}

Agbor E., Tambi D. (2014). Determinants of the HIV/AIDS epidemics prevalence in Cameroon. International Journal of Research and Review, 1(2), 8-19.

Angrist J. (2001). Estimation of Limited Dependent Variable Models with Dummy Endogenous Regressors: Simple Strategies for Empirical Practice. Journal of Business and Economics Statistics, 19(1).

Bascle G. (2008). Controlling for Endogeneity with Instrumental Variables in Strategic Management Research. Strategic Organization, 6(3), 285-327.

Becker G. (1965). A theory of the allocation of time. The Economic Journal, 75(299), 493-517.

Blau D., Grossberg T. (1990). Maternal Labor Supply and Children's Cognitive Development. The Review of Economics and Statistics, (74), 474-481.

Booysen F., Geldenhuys J., Marinkov M. (2003). The Impact of HIV/AIDS on the South African Economy: A Review of Current Evidence. TIPS/DPRU conference on "The Challenge of Growth and Poverty; the South African economy since democracy".

Dawn C., Kathryn H., Maction K. (2009). A Qualitative Study of the Impact of HIV/AIDS on Agricultural Households in Southeastern Uganda. International Journal Environ Respublic Health, 6(8), 2113-2138.

Dow W. (1999). Flexible Discrete Choice Demand Models Consistent with Utility Maximization: An Application to Health Care Demand. American Journal of Agricultural Economics, 81(3), 680-685.

FAO. (2002). The Impact of HIV/AIDS on rural households and land issues in Southern and Northern Africa. Economic and Social Development Department, Food and Agricultuiral Organisation, Corporate Document Repository.

Hamusimbi C., Mataa M., Jere G. (2006). Impact of HIV and AIDS on agriculture and food security in SADC: The case of Zambia; Food. Agriculture and Natural Resources Policy Analysis network.

Hofferth S.L. (1996). Effects of Public and Private Policies on Working after Childbirth. Work and Occupations, 23(4), 378-404. doi: 10.1177/0730888496023004004

Joesch J. (1997). Paid leave and the timing of women's employment before and after birth. Journal of marriage and the family, (59), 1008-1021.

Jones C. (2007). Why Have Health Expenditures as a Share of GDP Risen So Much? U.C. Berkeley.

Ilinigumugabo A. (1996). The economic consequences of AIDS in Africa. African Journal of Fertility, Sexuality and Reproductive Health, 1(2), 153-161.

Isaksen J., Songstad N., Spissoy A. (2002). Socio-economic effects of HIV/AIDS in African countries. Chr. Michelsen Institute.

Kormawa A. (2013). Impact of HIV/AIDS on African Agriculture and the role of the Consultative Group on Agricultural Research. Africa Rice Center (WARDA), B.P. 2031 Cotonou, Benin. 
Leibowitz A., Klerman J. (1995). Explaining changes in married mothers' employment over time. Demography, 32(3), 365-378.

Morrill S. (January 11, 2008). The Effects of Maternal Employment on the Health of School-Age Children. Job Market Paper. University of Maryland, College Park.

Murray C. (2006). Avoiding Invalid Instruments and Coping with Weak Instruments. Journal of Economic Perspectives, 20(4), 111-132.

Mwabu G. (2009). The Production of Child Health in Kenya: A Structural Model of Birth Weight. Journal of African Economies, 18(2), 212-260.

Ndirangu L., Kimalu P. (2012). The Effects of HIV/AIDS on Agricultural Production and Poverty in Kenya. IDEAS at the Research Division of the Federal Reserve Bank of St. Louis using RePEc data. http://purl.umn.edu/9538

Scicchitano J., Whitlock R. (2002). Quantifying the Effects of HIV/AIDS On Agricultural Production: A Guide From Rural Burkina Faso. Danish International Development Agency.

Stover J., Bollinger L. (March 1999). The Economic Impact of AIDS. The Futures Group International in collaboration with: Research Triangle Institute, The Centre for Development and Population Activities.

Tambi D.M. (2014). Modeling the effects of Mother's Age at first birth on child health at birth. Asian Journal of Economic Modelling, 2(1) 1-17.

Topouzis D. (December, 2000). Measuring the impact of HIV/AIDS on the agricultural sector in Africa. Joint and Cosponsored Program on AIDS. Geneva: UNAIDS.

UNAIDS Costs of Scaling HIV Programmes to a National Level for Sub-Saharan Africa. (April 2000). Draft report.

United Nations. (2010). The Impact of AIDS. United Nations Department of Economic and Social Affairs. Population Division.

\section{Article history:}

Received: 01 October 2018

Revised: 10 December 2018

Accepted: 18 January 2019

\section{For citation:}

Tambi M.D. (2019). HIV/AIDS pandemic and agricultural production in Cameroon. RUDN Journal of Economics, 27(1), 72-89. DOI: 10.22363/2313-2329-2019-27-1-72-89

\section{Bio Note:}

Mbu Daniel Tambi, Department of Agricultural Economics, University of Dschang, Cameroon. Contact information: tambi2015@yahoo.co.uk 


\title{
Пандемия ВИЧ/СПИДа и сельскохозяйственное производство в Камеруне
}

\author{
М.Д. Тамби \\ Университет Джанга \\ Камерун, Джанг, Боит Постале, 96
}

\begin{abstract}
В статье рассматривается степень влияния уровня распространения ВИЧ и СПИДа на сельскохозяйственное производство в Камеруне. Целью исследования является оценка факторов, влияющих на распространенность ВИЧ/СПИДа, а также изучение влияния ВИЧ/ СПИДа на сельскохозяйственное производство в Камеруне. В качестве основного источника информации взяты данные по обследованию потребления домашних хозяйств 2007 г., а также статистические данные профильных министерств, отвечающих за здравоохранение и сельское хозяйство в Камеруне. Основные результаты исследования получены путем применения двухэтапного метода регрессии наименьших квадратов. Результат исследования показал, что распространенность пандемии ВИЧ/СПИДа в Камеруне сильно зависит от уровня образования, возраста, профессии и экологических характеристик. В то же время данный метод продемонстрировал, что распространенность ВИЧ/СПИДа отрицательно коррелирует с сельскохозяйственным производством. Важность данных результатов определяется необходимостью совершенствования государственной сельскохозяйственной политики Камеруна с целью снижения негативного эффекта для системы здравоохранения и сельскохозяйственного комплекса страны.
\end{abstract}

Ключевые слова: ВИЧ/СПИД; эпидемия; сельскохозяйственное производство; государственное регулирование; Камерун

\section{История статьи:}

Дата поступления в редакцию: 01 октября 2018

Дата проверки: 10 декабря 2018

Дата принятия к печати: 18 января 2019

\section{Для цитирования:}

Tambi M.D. HIV/AIDS pandemic and agricultural production in Cameroon (Пандемия ВИЧ/ СПИДа и сельскохозяйственное производство в Камеруне) // Вестник Российского университета дружбы народов. Серия: Экономика. 2019. Т. 27. № 1. С. 72-89. DOI: $10.22363 / 2313-2329-2019-27-1-72-89$

Сведения об авторе:

Тамби Мбу Даниэль, факультет экономики сельского хозяйства, Университет Дшанг, Камерун. Контактная информация: e-mail: tambi2015@yahoo.co.uk 